Fecha de recepción: marzo 2020 Fecha de aceptación: abril 2020 Versión final: junio 2020

\section{On heroines and the ethics of revenge: Emma Zunz and Borges' metaphilosophy}

\begin{abstract}
The story Emma Zunz is a rara avis in the production of Jorge Luis Borges in two ways. First, women are rarely the main protagonists in his fictions. Second, while Borges explores philosophical themes in a significant number of his stories and essays (and poems), ethical issues are hard to find. In this paper I propose a way of understanding Borges' peculiar engagement with philosophical elements throughout his work, with some observations about the "Borgean metaphilosophy". Following that framework, and comparing Emma Zunz as a character with other female characters in Borges, I argue that the ethical elements in the story Emma Zunz are better understood as shaping a heroine story more than as exploring ethical issues of justice, retribution and revenge.
\end{abstract}

Keywords: Emma Zunz - Jorge Luis Borges - heroine - philosophy in Borges - retribution.

[Abstracts in spanish and portuguese on the pages 266-267]

(1) Marcelo Sabatés is Licenciado in Philosophy (UBA) and Master and Ph.D. in Philosophy (Brown University), with postdoctoral studies in Oxford University. His research interests have been mainly in Metaphysics and Philosophy of Mind, but they also include Latin American Thought and Culture and Internationalization in Education. He has published in some of the most important journals in his main disciplines and has co-edited several books, including Qualia and Mental Causation in a Physical World (Cambridge University Press). He has received awards or fellowships from the British Council, the National Endowment for Humanities, CONICET and Antorchas Foundation and has given lectures in over 15 countries. Currently he is Professor in Philosophy at Columbia College Chicago, and previously was Vice-Provost in charge of international areas both at Columbia College and Kansas State University, where he was also Head of the Philosophy Department. He was also co-founder and inaugural President of the Latinx Alliance in Kansas (ALIANZA). 
The story Emma Zunz is a rara avis in the production of Jorge Luis Borges in two ways. First, women are very rarely protagonists in his fictions. Second, while Borges explores philosophical themes in a significant number of his stories and essays (and poems), ethical issues are hard to find. Unlike some other female characters in Borges' fictions, Emma Zunz qua female character is essential to the development of the story. And the story is one where justice is explored under the gaze of retribution, where vengeance is assumed as an ethical imperative. In this paper I explore a way of understanding Borges relationship with philosophy both through his frequent use of it in his literature and through his not that frequent conceptualization of it as a discipline. I propose a distinctive way of understanding his engagement with philosophical elements throughout his work, with some observations about his idea of philosophy, or "Borgean metaphilosophy". ${ }^{1}$ Following that framework, and comparing the story to other stories with female protagonists, I argue, against some interpretations, that the ethical elements in Emma Zunz are better understood as shaping a heroine story which is fairly unique in Borges' production more than as exploring ethical issues of justice, punishment, retribution and revenge.

Before starting, there are two connected issues I want to clarify. First, I will remain neutral, for the purposes of this article, regarding the often-discussed issue of Borges' lack of political and social commitment, or even interest in them. ${ }^{2}$ Second, I will avoid an extra-textual perspective connecting Borges' texts and their contexts as informed by Borges' personal life and his dealings with political circumstances. In particular, I will avoid any interpretation or analysis of the potential relationship between Borges' lack of female characters and his peculiar relationship with women. ${ }^{-3}$ Overall, I will practice what I would call "relational textualism", where I center on the stories themselves and their relationship with the rest of Borges' corpus. ${ }^{4}$

\section{Philosophy in Borges and Philosophy for Borges}

An extraordinarily high number of Borges' fictions contain substantive philosophical elements. These are stories that use philosophical views, discussions or puzzles in their development, most times explicitly, sometimes implicitly. Almost as prominent but less frequent are the essays that revolve around philosophical themes. These are normally analyses of claims or issues where Borges carefully presents options regarding a topic and insightfully explores them.

In the case of his fictions, topics normally range from the nature of time, reality, language, art and philosophical themes close to theology. Well-known examples include, to give a very short list, "Pierre Menard, Author of the Quixote", "Tlön, Uqbar, Orbis Tertius, "Funes the Memorious", "The Aleph" and "The Circular Ruins". Some of Borges' fictions themselves have been the subject of philosophical discussion, or points of departure or exemplification of philosophical views. In fact, as a testimony of the unique and original character of Borges' use of philosophy, and, perhaps, as I will conjecture later, as a testimony of his somewhat hidden metaphilosophy, the "same" philosophy in Borges has been utilized to make totally different points within philosophy itself. For example, 
the celebrated classification of animals that he attributes to the imaginary Chinese Encyclopedia "Heavenly Emporium of Benevolent Knowledge" has been recruited for opposite purposes: Michael Foucault uses it to express skepticism about the ability of language (or maybe any conceptual framework) to capture reality, while logic or even computer programming textbooks use it as the inspiration to point out the common mistakes we make when we depart from the appropriate way of classifying. ${ }^{5}$

However, as noted above, there is a different source of philosophical engagement in Borges, which is the essays. Less prominent as matter of discussion in philosophy, Borges usually presents a puzzle or view, in a way that is literary but at the same time reflects philosophical rigor. "Avatars of the Tortoise", "A New Refutation of Time", "The Mirror of Enigmas", "The Fearful Sphere of Pascal" and "The penultimate Version of Reality" among others are included in this group. In most of these essays, he shows his fascination with idealism, normally the version of it captured by the claim that the external world and/or time do not exist/are illusions/are products of some/our mind(s). He can be seen as embracing the view in several essays, well beyond the exploration of it. For instance, in one of his essays on Zeno's paradoxes, he concludes that "Zeno is uncontestable unless we confess to the ideality of space and time. Let us accept idealism."'

Borges coziness with idealism is not limited, of course, to his essays. In his fictions, including some of the most famous ones, idealism is a common occurrence too. Some notable examples are the idealist community in "Tlon, Uqbar, Orbis Tertius" and the "dreamt dreamer" in "The Circular Ruins". In the very incomplete A Dictionary of Borges by Evelyn Fishburn and Psiche Hughes (1990), of which, interestingly, there is no translation to Spanish, the authors identify nineteen references to Schopenhauer and thirteen to Berkeley, some of the most influential idealist thinkers in the history of philosophy. One the other hand, the count is very different when it comes to the skeptics: There are no references to Sextus Empiricus or Montaigne, the sole reference to Cicero is not from De Academica, and the few references to Descartes have no relation with his methodical skepticism. One would think this contrast is fully consistent with the mentioned fascination and with some textual evidence declaring his sympathies, for example: "I have examined those (philosophies) which enjoy certain prestige; I venture that only in the one formulated by Schopenhauer have I recognized some trait of the universe."

That is the Borges that uses philosophy in his literature, including his essays. So from the pervasiveness of idealism together with Borges' vast philosophical culture we may conclude that he is truly a philosophical idealist. Still, let's display the quotation just shown in its entirety. "I have examined those (philosophies) which enjoy certain prestige; I venture that only in the one formulated by Schopenhauer have I recognized some trait of the universe [...] it is venturesome to think that a coordination of words (philosophies are nothing more than that) can resemble the universe very much. It is also venturesome to think that of all these illustrious coordinations, one of them - at least in an infinitesimal way-does not resemble the universe a bit more than the other." "

Borges talking about philosophy as a discipline, or as I put it, "Borges' metaphilosophy" defends the view that philosophies are just coordinations of words. This is reinforced in many instances in which Borges talks about philosophy or his use of it. In the Epilogue 
of "Other Inquisitions", for instance, he says that he has learned to "to praise religious or philosophical ideas for their aesthetic value and even for what they have of singular and marvelous. This is perhaps a sign of essential skepticism".

I am not claiming here necessarily that Borges is defending skepticism regarding our possibility of knowing the external world or any other realm, as opposed to the version of idealism defending that the external world or any other realm do not exist/are illusions/ are products of some/our mind(s). I am rather saying that his "essential skepticism" runs deeper. ${ }^{10}$ It is a metaphilosophical view about the discipline, claiming that philosophy is to be appreciated not by how well it describes or explains reality, knowledge, values, or any other area it approaches, but by its aesthetic (or literary) characteristics: On how fertile philosophical ideas are for fiction. In interviews or other texts he makes the same point in creative ways, for instance: "Philosophy and theology are branches of fantastic literature" or "I am simply a reader [of philosophy]. I am unable to engage myself in philosophical thinking. I have no theory of the world [but] as I have used metaphysical and theological systems for literary purposes, readers have thought that I professed those systems; what I did was to use them for these purposes". (This is of course compatible with honest intellectual fascination with some of those "coordinations of words" beyond the use he could make of them in literature.)

To conclude, Borges metaphilosophy should be kept in mind as the primary factor while analyzing the philosophical elements in his work. ${ }^{11}$ This means that Borges choses the philosophical themes and views that would offer the most possibilities from an aesthetical standpoint.

\section{Emma Zunz, a Unique Character in Borges' Corpus}

A survey of the prose of Jorge Luis Borges clearly reveals the scarcity of female characters in primary roles or even as characters that are relatively central in a story. In a classical article on women in Borges' writings, E. D. Carter Jr. says that "[w]omen appear as more than secondary or peripheral characters in only nine of [Borges'] works."12 In a more recent article, María Fernandez-Lamarque affirms that only thirteen of Borges' stories have female presence and that in many of them their role is secondary or they are basically absent. ${ }^{13}$ The subset of stories with significant female presence is, thus, much smaller, reaching perhaps a half dozen. And even in such a small group, there are cases where the limitations of the character as a significant female character are obvious. Two examples: In "Story of the Warrior and the Captive", the protagonist is, without doubt, a female: The "blond Indian woman" (for whom we never get a name), the captive born in the Yorkshire (England) who after relocating to Buenos Aires with her parents as a girl lost her family to an "Indian raid" and was "carried off by the Indians and was now the wife of a chieftain" with whom she had two sons. She embraced the native culture and language "carried away by a secret impulse, an impulse deeper than reason". When offered by Borges' own grandmother ${ }^{14}$, another Englishwoman, protection and support, at a casual encounter, the woman declines saying she was happy and going back to the desert. Interestingly, 
this story is prefaced by Borges retelling a story he found in Benedetto Croce: The story of Droctulft, a Barbarian (Lombard) warrior that, at some point between the V and VIII centuries, deserted to the Romans in the siege of Ravenna. As the blond Indian woman "he was not a traitor [...], he was a visionary, a convert." ${ }^{15}$ The fact that the gender of the character is fully contingent to the structure is stressed by the way Borges ends the story: "Perhaps the stories I have recounted are a single story. To God, the obverse and reverse of this coin are the same"16

In "The Intruder", the often-studied character of Juliana can be seen as a central piece in the description, and criticism ${ }^{17}$, of a violent, patriarchal culture. Juliana is brought by the older of two brothers to live at the brothers' house, partly as a mistress, partly as a servant. After some time, with the younger brother falling in love with Juliana and perhaps un underlying homoerotic element, one evening the older brother tells the younger one: "I'm leaving for a party at Farías' place. Juliana is over there: if you want, use her. [...] From that night on they shared her."18 With time, tensions escalate and the brothers decide first to sell her to a house of prostitution and then, after both brothers secretly visit her at the brothel, to kill her. Still, with all the centrality of her character in the tragic tale of subjugation and cruelty, Juliana is a fully passive, objectified character. She is just a vehicle to make evident the machismo and its associated features of including a pathological resistance to understand a woman as an equal. In one sense, the fact that she is a woman is key to illustrate gender oppression, on the other hand, this is not done by her showing agency of any sort but by describing how she is "a thing".

In this context, Emma Zunz ${ }^{19}$ is quite different. No "universality" that can include a nonfemale character, no passivity to instantiate male chauvinism. The story is set in Buenos Aires in the 1920s. Eighteen years old Emma lives alone in the blue collar neighborhood of Almagro and works at a textile mills company. She receives a letter from Brazil written by an unknown person saying that her father, a fugitive from Argentinean justice, "had taken by mistake a large dose of veronal and had died" in a hospital in Bagé. Her father had been accused of embezzling from the company she works at, but right before fleeing to Brazil, he had told Emma that the thief was not him, but Aaron Loewenthal, a former manager of the company who was now co-owner. Borges describes Emma's feelings and actions after reading the letter in a masterful way, which sets the tone of his deep psychological exploration of her thorough the story:

"Emma dropped the paper. Her first impression was of a weak feeling in her stomach and in her knees; then of blind guilt, of unreality, of coldness, of fear; then she wished that it were already the next day. Immediately afterwards she realized that that wish was futile because the death of her father was the only thing that had happened in the world, and it would go on happening endlessly. She picked up the piece of paper and went to her room. Furtively, she hid it in a drawer, as if somehow she already knew the ulterior facts. She had already begun to suspect them, perhaps; she had already become the person she would be."20

The "ulterior facts" are the ones that constitute the plot: Emma sees Loewenthal -who is her boss at the mills- as responsible for her father's death and decides to punish him. To 
do this, she develops a plan that, in both necessary and surprising ways, includes selfpunishment. Emma, a virgin, finds a foreign sailor in an area no one would know her (the Buenos Aires harbor area) who pays her in exchange for sex. Immediately following this, she finds an excuse to visit Loewenthal on a non-working day and kills him taking a revolver from the desk drawer of his office. She calls the police and repeatedly claims that he raped her and that she had no option but to kill him.

Once the "call to action" ${ }^{21}$ comes in the form of the letter, Emma first cries and remembers:

"In the growing darkness, Emma wept until the end of that day for the suicide of Manuel Maier, who in the old happy days was Emmanuel Zunz. She remembered summer vacations at a little farm near Gualeguay, she remembered (tried to remember) her mother, she remembered the little house at Lanús which had been auctioned off, she remembered the yellow lozenges of a window, she remembered the warrant for arrest, the ignominy $[\ldots]$ ". ${ }^{22}$

She then quickly moves to being in charge, and, from the "slightest fact" that she was the only one to know what had happened in the mills, to unexpectedly gain power until the end of the story:

"Since 1916 she had guarded the secret. She had revealed it to no one, not even to her best friend, Elsa Urstein. Perhaps she was shunning profane incredulity; perhaps she believed that her secret was a link between herself and her absent father. Loewenthal did not know that she knew; Emma Zunz derived for this slight fact a feeling of power."23

When justice calls to avenge a wrong, an unlikely heroine is in the making from a shy, forgotten, ordinary young woman.

\section{Justice, Punishment, Retribution and Revenge as Shapers of the Heroine}

A good portion of the philosophical literature on punishment centers on the issue of institutional punishment. Retribution ${ }^{24}$ is the concept standardly used to characterize one of the two most influential ways of understanding how justice is implemented through punishment. Underlying the retributive concept of justice and punishment is the thought that an action that is morally wrong deserves, in a moral and a posteriori legal/social sense, some sort of punishment that is, in a way to be determined, commensurate to the wrongness of the action. Accompanying that thought is the idea that independently of any consequences (deterrence ${ }^{25}$, for instance), punishing a wrong is morally right. When we move from institutional to non-institutional (personal) punishment, a common psychological factor associated with retribution is the desire for revenge. Robert Nozick lucidly distinguishes between retribution and revenge in the following way: "Revenge involves a particular emotional tone, pleasure in the suffering of another, while retribution 
either need involve no emotional tone, or involves another one, namely, pleasure at justice being done". ${ }^{26}$ While this distinction is a valuable one for the purposes of a moral or legal theory of punishment, in the context of seeking justice at a personal level, revenge is the fire igniting retributive justice, and the punishment that comes from it.

Emma's actions and thoughts after receiving the letter, her omnipresent need to avenge her father and to seek justice through retribution, of course introduce the philosophical issues of justice and punishment. Understandably, it can be thought that the story contains the elements of moral and even legal deliberation. ${ }^{27}$ Still, Borges does not engage, in any significant sense, in reflection about the type of justice that retribution brings, and much less its justification: Its fairness is a given in Emma's mind, a given with no alternatives, neither theoretical nor practical. Emma's certainty is so far from a philosophical attitude that it seems obvious that Borges is just playing with a philosophical view, the retributionist view of punishment, and its psychological instigator, revenge, rather than building any philosophical atmosphere in the story (for the same reason, we cannot see Borges glorifying revenge or even defending that an instance of revenge could be justified or reasonable). Revenge-based retribution is used for what it has of singular: A more neutral, less passionate idea of punishment, or even a more water down idea of retribution would not have been enough to sacrifice herself to avenge her father. ${ }^{28}$ Nor to put her in a position of power. Nor, ultimately, to transform her into a heroine. ${ }^{29}$

In fact, it is remarkable that the space of potential reflection about moral responsibility, where guilt would play as a justifier of retribution, never actually happens:

"Things did not happen as Emma Zunz had anticipated. Ever since the morning before, many times she had imagined herself wielding the firm revolver, forcing the wretched creature to confess his wretched guilt, and exposing the daring stratagem which would allow the justice of God to triumph over human justice. [...] But things did not happen that way"30

Emma was, at that point, so much into her journey of being in power that, as Borges says, "she [did not] have time for theatrics". The need for justice through retribution, the thirst for revenge are the factors that make hesitation impossible when confronted with the wrong (or wrongs) surrounding her.

To reinforce this point we can compare Emma with the character of Dulce Rosa Orellano in Isabel Allende's short story "An Act of Vengeance". ${ }^{11}$ The story is, also, a tale of revenge where the main character is a woman with a richly explored psychology, like Emma Zunz. Allende's is a story about a very young woman who is raped by a man, a Caudillo, who also kills her father. Dulce Rosa, like Emma, plans her vengeance (something she had promised to her father) soon after the facts. But the retribution takes so long, and it includes what initially is a plotted wedding to make justice, that she falls in love with the assassin. At that juncture, she has no option but killing herself, the only way open to her to keep the promise to her father and reach retribution. While the price paid by Dulce Rosa and Emma is extraordinarily high in both cases, only Emma ends up achieving the heroine's ultimate retribution: Dulce Rosa is unable to kill the target of her vengeance. Of course it could be said that in Allende's story Dulce Rosa's suicide amounts to an equal (or worse) 
event for the assassin compared to killing him. However, I venture that that potential way of rationalizing the ending of Allende's story contains a romanticized view of the psychology of a ruthless individual and, more importantly, of its reflection on Dulce Rosa's own psychology, making her less of a heroine than Emma. In any case, the fact that revenge is far more prominent in Emma than in Dulce Rosa is the stage for such difference. A final element needs to be considered regarding the essence of the structuring role in the story. Emma's journey goes through an ordeal including painful, atrocious sacrifice. To be able to claim rape, and thus self-defense, she:

"[...] came across men from the Nordstjärnan. One of them, very young, she feared might inspire some tenderness in her and she chose instead another perhaps shorter than she and coarse, in order that the purity of the horror might not be mitigated. [...] The arduous events are outside of time, either because the immediate past is as if disconnected for the future, or because the parts which form these events do not seem to be consecutive. [...] The man, a Swede or a Finn - did not speak Spanish; he was a tool for Emma, as she was for him, but she served him for pleasure, whereas he served her for justice. ${ }^{32}$

This brings us back to the point in the previous section about Emma uniqueness as a character in Borges' stories in the sense of being an essentially female agent. Revenge takes a form of self-sacrifice which essentially involves a female character -a character that is explored with all the richness of an everyday young woman in early XX century Buenos Aires. A potential objection to this essentiality of a woman character in the story would be to point out that Emma's father, who was living in Brazil under the name of Manuel Maier, had a pre-exile name: Emmanuel Zunz. "Emma" the name, as it has been noted, is in fact part of "Emmanuel" ${ }^{33}$, suggesting that Emma the character is just the part of her father who seeks revenge. I propose the opposite reasoning. In fact, "Emmanuel", the name of the "old, happy days" of Manuel Maier, is a name that is only restored after Emma decides to victimize herself in the process of taking revenge for her father's exile and death. It is Emma's agency as a female that brings the name back.

\section{Final Remarks}

Borges' use of the themes of retribution and vengeance regarding justice have a purely literary role in Emma Zunz. They do not amount, of course, to a defense of a retributive view of punishment, and they don't even amount to a substantive exploration of the philosophical issue of punishment and its relation with the notion of justice. The literary value is an exploration of the moral psychology of revenge, which in Borges' pen triggers a fascinating short story in which a heroine emerges, against all odds, in a male-dominated environment. This is consistent with Borges' metaphilosphy according to which philosophical themes are to be used, as he says in the epilogue of Other Inquisitions, "for what they have of singular and marvelous". 


\section{Notes}

1. I understand "metaphilosophy" as the reflection on the type of activity philosophy is, including, but not limited to, reflection on its scope, methods and the nature of the claims it makes.

2. This is an issue that, of course, is interesting in itself, not just to illuminate more contextual analyses of Borges work, but also because of the unusual position Borges had in this respect vis-à-vis other great writers in recent Latin American history. This is very eloquently expressed by Bella Brodzki when noting that Borges has been "reviled for his indifference to the tragedies of human experience" given that "when Borges' fiction and non fiction are seen in modern Latin American social and political context, its rarified, solipsistic universe begins to resemble not so much the library as the mausoleum [...]" (1990, p. 149). Brodzki, however, adds a claim about Borges' disregard for his own cultural tradition which I would disagree with. This connects with another axis of a more contextual analysis which is the supposed universalism of Borges work. Beatriz Sarlo (1990) convincingly argues for an 'Argentinization" in the interpretation of Borges (as opposed to the universalist readings of him) on the one hand by making explicit Borges' knowledge and use of Argentinian history and traditions and, on the other hand, acknowledging the hybridity of Argentinean culture as an intersection of the Latin American and the European.

3. There is a fairly extensive body of criticism along these lines, with either biographical or political or psychoanalytic flavors. See for instance Fitzgerald (2006) and Vazquez (1996). 4. I add to the strictly literary corpus, some "metaliterary" and "metaphilosophical" views in which he illuminates his aesthetics.

5. See Foucault (1970) and Kelley, D. (2014)

6. The view that Borges was an extraordinarily lucid philosophy reader is widely shard. I venture to say that around 1930 there were very few people in Argentina, including "professional" philosophers, who could be conversant, at the same time, in the history of philosophy, and the so-called continental and analytical traditions. As an example of his historical knowledge, see the wonderful book on Borges and medieval philosophies by Silvia Magnavacca (2009). Personally, I was always surprised of his grasp of some technical aspects of Bertrand Russell's philosophy as shown, for instance, in "The Perpetual Race of Achilles and the Tortoise" (1929), where he describes Russell's Introduction to Mathematical Philosophy and Our Knowledge of the External World as "books of inhumane lucidity, unsatisfactory and intense" (1974), p. 246. All translations from the Obras Completas are mine.

7. "The perpetual Race between Achilles and the Tortoise", in (1974), p. 248.

8. "Avatars of the Tortoise" in (1962), p. 207.

9. Again, "Avatars of the Tortoise" in (1962), p. 207.

10. Of course, Borges was surely aware that metaphilosophical skepticism implies, with fairly innocuous assumptions, skepticism in every area of philosophical theorizing. In an interview with María Ester de Miguel, for instance, he moves closer to epistemological skepticism: "I don't have any certainty, not even the certainty of uncertainty. Thus I believe that any thought is conjectural". 
11. I have explored the connection between Borges' use of philosophy and his metaphilosophical view with the background of the distinction between idealism and skepticism about the external world in an analysis of "The Circular Ruins" in my (2011). 12. E.D. Carter (1979), p. 13.

13. María Fernandez-Lamarque (2012). The small discrepancy between the two accounts is explained by the fact that Carter does not count very peripheral characters. In her article, Fernandez-Lamarque notes that several of Borges' female characters do not even have a proper name and are referred to by a nickname or a definite description. One of those cases is the character in "Story of the Warrior and the Captive", which I will briefly analyze below.

14. Borges, hopefully with irony, explains his grandmother's perception of the blond Indian woman's predicament this way: "A savaged life could be glimpsed behind her story: The horsehide shelters, the fires made of dry manure, the feasts of scorched meat or raw entrails, the stealthy departures at dawn, the attacks on corrals, the yelling and the pillaging, the wars, the sweeping charges on the haciendas by naked horsemen, the polygamy, the stench and the superstition. An Englishwoman had lowered herself to this barbarism." (p. 559)

15. Borges (1974), p. 558

16. Borges (1974), p. 560

17. I agree with those who, like Bella Brodzki, claim that "to read this story only as a celebration or glorification of misogyny is possibly to miss Borges' critical commentary and to understand its context (and content) only on the level of 'naturalistic' transcription of a cultural reality." (1990, p. 156)

18. Borges (1974), p. 1026.

19. Fernandez Lamarque argues that only "El Zahir" and "El Aleph" have female characters that are not just fundamental to the story but also essential to their structure. I would add Emma Zunz to this very short list, for reasons that will become apparent later. 20. Borges (1962), p. 132

21. See note 28 .

22. Borges (1962), p. 132-3

23. Borges (1962), p. 132

24. The fact that retribution as a justification for punishment is so strongly present in the Jewish tradition to which Emma Zunz and Loewenthal belong to is not a side note in Borges' use of it. But that analysis goes beyond the scope of this paper.

25. A deterrence view of punishment, which is normally opposed to retributionism, claims that justification for punishment comes not from any intrinsic element of punishment itself but from the fact that punishing deters both the offender and other possible offenders from performing the wrong act.

26. Nozick (1981), p. 367.

27. See, for instance, Rosa Vila's (2014).

28. Of course, Borges is not alone here: Hamlet and Captain Ahab, among so many others, are in good company. 
29. I am taking the term "heroine" in a standard, pre-theoretical sense. Thus, I am not linking it to views that stipulate certain conditions for someone to be a hero/heroine. One could be tempted, following Campbell (1949), to recognize certain sequence (or better, elements) in the story as instantiating some of Campbell's stages. For instance, the call to adventure would be receiving the letter from an unknown person from Brazil, the ordinary world would be found in references to the "happy days" and the current degraded situation of Emma which is mentioned after she reads the letter, the crossing of the threshold could be (symbolically) hiding the letter in a drawer, the ordeal is the undesired sexual experience, and so on. But I am not taking "heroine" as a concept defined by Campbell or alternative theoretical views like Murdock's (1990). For a lucid comparison of those models, see Steiff (2019).

30. Borges (1962), p. 136.

31. In Isabel Allende (1989). Of course Allende's story includes an element absent in Emma Zunz, which is how deep destruction goes in episodes of political violence and war. In a Borgean twist, the translator to English of "An Act of Vengeance" is no more and no less than a pioneer of the analysis of female characters in Borges: E. D. Carter Jr. 32. Borges (1962), pp. 134-5.

33. See, for instance, Linda Maier's (2002). While I have not seen this explicitly as an objection, the relation between the names invites the point.

\section{Bibliography}

Allende, Isabel (1990). Cuentos de Eva Luna. Plaza y Janes.

Borges, Jorge Luis (1974). Obras Completas. Emecé.

Borges, Jorge Luis (1962). Labyrinths. Selected Stories and Other Writings. Edited by Yates, Donald and Irby, James. New Directions Publishing Company.

Brodzki, Bella (1990). "Borges and the Idea of Woman", Modern Fiction Studies, vol. 36, pp. 149-166.

Campbell, Joseph (1949). The Hero With A Thousand Faces. Pantheon Books.

Carter Jr., E. D. (1979). "Women in the Short Stories of Jorge Luis Borges", Pacific Coast Philology, vol. 14, pp. 13-19.

Fernandez-Lamarque, María (2012). "Women in Borges: Teodelina Villar in 'El Zahir" in Women in Latin American and Spanish Literature, edited by Eva Bueno and María Claudia André. Mc Farland, pp. 178-194.

Fishburn, Evelyn \& Hughes, Psiche (1990). A Dictionary of Borges. Duckworth.

Fitzgerald, Donna (2006). "Borges, Woman and Postcolonial History." Romance Studies vol. 24, pp. 227-239.

Foucoult, Michael (1970). The Order of Things: An Archeology of the Human Sciences. Random House, Inc.

Kelley, David (2014). The Art of Reasoning. 4th Edition. W. W. Norton \& Company.

Magnavacca, Silvia (2009). Filósofos Medievales en la Obra de Borges. Miño y Dávila Editores. 
Maier, Linda (2002). "What is in a Name? Nomenclature and the case of Borges' 'Emma Zunz"'. Variaciones Borges, vol. 14, pp. 79-87.

Murdock, Maureen (1990). The Heroine's Journey. Woman's Quest for Wholeness, Shambhala. Nozick, Robert (1981). Philosophical Explanations, Harvard University Press.

Sabatés, Marcelo (2011). “Three Versions of Borges”, presented at the American Philosophical Association Eastern Meeting.

Sarlo, Beatriz. (1993) Jorge Luis Borges: A Writer on the Edge. Verso.

Steiff, Joseph. (2019) "To Lose my Mind and Find my Soul. The Masculine and Femenine in Films Set in the Forest", Cuadernos del Centro de Estudios de Diseño y Comunicación, vol. 91, pp. 249-258.

Vásquez, María Esther (1996). Borges: esplendor y derrota. Tusquets.

Vila, Rosa (2014). "Emma Zunz by Jorge Luis Borges: The Concept of Justice". Oñati SocioLegal Series, Vol. 4, pp. 1232-1240.

Sobre heroínas y la ética de la venganza: Emma Zunz y la metafilosofía de Jorge Luis Borges

Resumen: El cuento Emma Zunz es una rara avis en la producción de Jorge Luis Borges en dos sentidos. Primero, las mujeres raramente son las protagonistas de sus cuentos. Segundo, mientras Borges explora temas filosóficos en un número significativo de sus ficciones y ensayos (y poesías), las cuestiones éticas son dificiles de encontrar. En este trabajo propongo una manera de comprender la forma peculiar en la que Borges usa elementos filosóficos en su obra, son algunas observaciones sobre la "metafilosofía Borgeana". Siguiendo ese marco de referencia, y comparando el personaje de Emma Zunz con otros roles femeninos en Borges, argumento que los elementos éticos en la historia de Emma Zunz son mejor comprendidos como dándole forma a una historia de heroína más que como una exploración de los temas éticos de la justicia, la retribución y la venganza.

Palabras clave: Emma Zunz - Jorge Luis Borges - heroina - filosofía en Borges - retribución.

Sobre heroínas e a ética da vingança: a metafilosofia de Emma Zunz e Jorge Luis Borges

Resumo: O conto Emma Zunz é um rara avis na produção de Jorge Luis Borges de duas maneiras. Primeiro, as mulheres raramente são protagonistas de as histórias de Borges. Segundo, enquanto Borges explora temas filosóficos em um número significativo de suas ficções e ensaios (e poesia), questões éticas são difíceis de encontrar. Neste trabalho, proponho um esboço para entender a maneira peculiar como Borges utiliza elementos filosóficos em seu escritos, com algumas observações sobre a "metafilosofia borgeana". Seguindo esse quadro de referência e comparando a personagem de Emma Zunz com outros papéis femininos em Borges, eu argumento que os elementos éticos na história de 
Emma Zunz são melhor compreendidos como moldando uma história de heroína do que como uma exploração dos temas éticos da justiça, retribuição e vingança.

Palavras chave: Emma Zunz - Jorge Luis Borges - heroína - filosofia em Borges - retribuição.

[Las traducciones de los abstracts fueron supervisadas por el autor de cada artículo] 